\title{
\#paslui: feminismos brasileiros no hexágono europeu
}

\author{
Larissa Pelúcio' (iD 0000-0001-6212-3629 \\ Diego Paz ${ }^{2,3}$ (iD 0000-0002-7575-4101
}

'Universidade Estadual Paulista Júlio de Mesquita Filho, Faculdade de Arquitetura, Artes e Comunicação de Bauru, Departamento de Ciências Humanas,

Bauru, SP, Brasil. 17033-360

${ }^{2}$ Universidade Católica de Pernambuco, Recife, PE, Brasil. 50050-900

3Universidade Paris 8, Paris, França. 75014

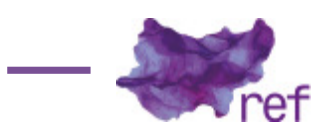

Resumo: Neste artigo, analisamos o movimento \#elenão e suas reverberações em contexto francês. Num movimento que ganhou repercussão transnacional, mulheres brasileiras organizadas por diferentes lógicas de opressão mostram agência política pelo uso das redes sociais digitais e, especificamente, de hashtags. De inspiração etnográfica, partiu-se de observações participantes da autora e autor nas manifestações que aconteceram na cidade de Paris, na França, no período das eleições de 2018, no Brasil, mas também de entrevistas com as organizadoras locais dos eventos. Mobilizando como operador analítico o conceito de political agency, ou capacidade de agir politicamente, segundo Judith Butler, argumentamos que este movimento, iniciado pelas mulheres, foi um elemento unificador de outras minorias políticas, como negros e LGBT+, contra o avanço do "neofascismo" e retrocessos no campo dos direitos humanos.

Palavras-chave: \#elenão Paris; eleições 2018; capacidade de agir politicamente; feminismos.

\#paslui: Brazilian Feminisms in the European Hexagono

Abstract: In this article, we analyze the movement \#NotHim and its repercussions in the French context. In a movement of transnational repercussion, brazilian women organized by different logics of oppression show political agency through the use of digital social networks and, specifically, hashtags. Inspired by ethnography, we started with participant observations by the author and author in the demonstrations that took place in the city of Paris, France, during the 2018 election period in Brazil, but also of interviews with local event organizers. Mobilizing as an analytical operator the concept of political agency, according to Judith Butler, we argue that this movement, initiated by women, was a unifying element of other political minorities, such as blacks and LGBT +, against the advance of the "neo-fascism" and setbacks in the field of human rights.

Keywords: \#NotHim Paris; 2018 Elections; Political Agency; Feminisms.

\section{\#elenão em francês é \#paslui}

Uma manhã, eu acordei E ecoava: ele não, ele não, não, não Uma manhã, eu acordei E lutei contra um opressor Somos mulheres, a resistência De um Brasil sem fascismo e sem horror Vamos à luta, pra derrotar O ódio e pregar o amor (2x) 
"Foi totalmente espontâneo e as mulheres aderiram e criaram 'palavras-de-ordem', criaram músicas, bolaram maneiras de fazer, bolaram cartazes. O mundo inteiro... todas as mulheres brasileiras tavam sendo tocadas e tavam sabendo, por causa do Face [Facebook]", conta-nos Naná sobre as articulações para a organização de um ato público contra a postura política do então candidato à presidência do Brasil, Jair Messias Bolsonaro. Ela acrescenta: "Aí, quando eu vejo que o negócio tá tomando forma eu digo 'não é possível ficar parada em Paris! Não tem porra nenhuma em Paris'. Aí eu comecei a minha velha mania ou deformação, procurei as brasileiras do PT, as militantes e deu certo".

Naná, como é conhecida Narcisa Beatriz Whitaker, militante de esquerda, feminista e exilada política de duas ditaduras, a brasileira (1964-1985) e a chilena (1973-1990), vive há mais 30 anos em Paris, onde tem mantido seu engajamento político. Nós a entrevistamos em um dia cinza do inverno parisiense e, depois daquela tarde de cafés e lembranças, estivemos com ela em outros momentos, como reuniões do grupo recém-formado de "Brasileiras Unidas" e na homenagem feita à vereadora carioca Marielle Franco, pelo um ano de seu assassinato. Nesse dia de homenagem, debaixo da fina e fria chuva, na Esplanade des Villes-Compagnons-de-la-Libération, monumento discreto que marca a memória das cidades que resistiram à ocupação nazista na França, Naná discursou relembrando os motivos daquele ato. Conceição Evaristo, também presente, leu uma poesia com uma vozinha miúda que nem aquela chuva insistente. Naquela altura, as eleições brasileiras já estavam decididas, Bolsonaro empossado e o clima entre suas opositoras era triste como aquela tarde de luto em Paris. Luto e luta têm sido substantivos relacionados aos sujeitos históricos que têm feito enfrentamentos contra a ordem hegemônica.

Neste artigo falamos de luta e resistência como modos de ação que passam por alianças e apropriações significativas de espaços públicos, bem como de articulações em redes, sobretudo, as digitais. Aqui, pretendemos analisar o acontecimento dos atos públicos contra a iminente chegada ao poder da extrema-direita no Brasil, mas que reverberaram em dezenas de cidades do mundo. Partimos de nossa própria experiência em Paris, onde pudemos acompanhar a organização de brasileiras contra o candidato à presidência do Partido Social Liberal (PSL), que se propagou a partir da hashtag \#elenão. Interessa-nos discutir a political agency, ou a capacidade de agir politicamente dessas mulheres, em diálogo com os aportes teóricos de Judith Butler, em especial suas contribuições que articulam noções como "agenciamento" e "sujeito".

A expressão anglófona political agency é cunhada por Butler e deriva de agency, conceitochave das primeiras teóricas feministas anglo-saxônicas (Anne MONTENACH, 2012) e que tem sua análise revista e reelaborada pelo trabalho da filósofa americana, que o associa à performatividade (Monique HAICAULT, 2012). Nessa nova perspectiva, agency permite escapar à dicotomia submissão/resistência e pensar o híbrido entre subversão e adaptação. É também um fenômeno coletivo, ou seja, a reivindicação de um agir coletivo torna possível uma capacidade de agir individual. Nesse sentido, agency ganha uma forte conotação política, como nos mostra o recente trabalho dessa filósofa, Corpos em aliança e a política das ruas (Judith BUTLER, 2019). ${ }^{1}$

Sem equivalente simples em português, agency tem sido traduzida diretamente, (i.e.) sem um debate que considere as vicissitudes da língua portuguesa e do contexto brasileiro, por agência. A similaridade com o léxico neoliberal - nomeando repartições públicas (agência dos correios), filial de banco (agência bancária) ou empresa comercial (agência de viagens, de imóveis etc.) nos incita a buscar alternativas que em nossa língua se aproximem mais dos sentidos que o conceito visa produzir em seu idioma de partida. Por outro lado, a tradução desse termo foi colocada no centro das reflexões de teóricas e teóricos franceses que recepcionavam a obra butleriana no hexágono europeu. ${ }^{2}$ Seja por resistência à influência cultural americana ou por rivalidade na hegemonia da produção intelectual, as trocas franco-americanas nunca se dão num campo apaziguado. Podemos então tirar proveito dos produtos intelectuais dessas disputas. Em síntese, nos valeremos, sobretudo, das proposições de Cynthia Kraus que, na ocasião da tradução de Gender Trouble (BUTLER, 1990) para o contexto francês, retém, em acordo com a autora americana, "capacidade de agir" ("capacité d'agir"), para agency, e "capacidade de agir politicamente" ("capacité d'agir en politique"), para political agency (Cynthia KRAUS, 2006).

Apostamos em entrevistas em profundidade com mulheres brasileiras que estiveram na raiz da organização da primeira manifestação \#elenão, somando a esta técnica a clippagem no

\footnotetext{
${ }^{1}$ Além da versão traduzida em português, consultamos a obra publicada originalmente em 2015, sob o título Notes toward a performative theory of assembly, e a tradução francesa Rassemblement: pluralité, performativité et politique, publicada em 2016. Conscientes das adequações necessárias que o trabalho de tradução impõe, consultamos, na maioria dos casos das obras da autora Judith Butler citadas neste artigo, as versões originais em inglês e as respectivas versões em língua francófona. Todavia, visando tornar mais fácil o acesso ao texto citado, decidimos referenciar as versões em língua portuguesa. Outras versões serão mencionadas quando suas especificidades forem pertinentes. 2 "O hexágono", ou, no idioma local, "l'hexagone", é uma metáfora utilizada localmente para se referir à França metropolitana (que considera apenas o território continental europeu), em função de seu formato visto no mapa, que lembra este polígono de seis lados.
} 
jornal francês de maior circulação no país; ${ }^{3}$ cotejando, sempre que necessário, com matérias publicadas em periódicos brasileiros em suas versões on-line e na observação participante em manifestações associadas ao movimento em questão. Valemo-nos, ainda, de informações postadas nas páginas da rede social digital Facebook associadas ao movimento no Brasil e França. Nosso texto pretende contar parte desta história, sobre a qual criamos um entre tantos registros possíveis, uma fotografia, de "uma história em aberto" (Eric HOBSBAWM, 1998). Escrevemos enquanto as veias estão abertas, os sentimentos quentes, a respiração ligeira. Assim, nossa narrativa reivindica o caráter de uma produção situada (e, como tal, parcial e precária), que se inscreve na perspectiva epistemológica-feminista, tal qual descrevem Sandra Harding (1986), Patricia Hill Collins (1986) e Donna Haraway (1988). ${ }^{4}$

\section{Atiçando o formigueiro}

"Ele não. Ele nunca. Ele jamais", entoaram manifestantes reunidas/os naquele 29 de setembro de 2018, na Place de Le République. "Finalmente vamos pra rua", exclama Mariana Schmitz, relembrando dos esforços de mobilização que ela, juntamente com outras brasileiras como Naná, ajudou a construir a partir de uma articulada convocação feita pelas redes sociais digitais. ${ }^{5}$ Sem muito jeito com as mídias digitais, Naná buscava parcerias a partir de associações e partidos políticos que reuniam brasileiras e brasileiros na França; foi assim que chegou até Carolina Giliolli Goos, também brasileira, fazendo doutorado em Comunicação em Paris. "As novas são muito legais, não são sectárias", avalia Naná, qualificando as feministas de sua geração. São "as novas" que sabem usar as redes sociais digitais, aposta a veterana. Foi conversando com essas brasileiras mais jovens que Naná soube que "alguém" já estava organizando pelo Facebook uma manifestação de Mulheres Contra Bolsonaro para acontecer em Paris. Na cozinha do apartamento de Carolina, na Maison du Brésil (residência universitária localizada no complexo da Cité Internationale Universitaire de Paris), as duas iniciaram o esforço de contatar Marina Schmitz, também brasileira, militante feminista, quem estava articulando o ato público que Naná procurava fazer acontecer.

Foi a oportunidade para sair do virtual e botar a gente na rua. Em toda essa experiência senti muita necessidade de ir para o mundo real, fora das telas, né? E aí o que aconteceu na verdade foi por acaso. Comigo que aconteceu foi o seguinte: eu tava acompanhando todo aquele engajamento virtual, participando [...] e aí eu resolvi criar um grupo para a gente discutir as questões da eleição no Face [Facebook]. E aí eu criei o grupo "Mulheres em Paris contra Bolsonaro". Nisso outro grupo foi fundado, que foi o "Mulheres contra Bolsonaro na França". Daí eram as mulheres da França inteira, né? E só que ninguém criava o evento do ato. $E$ aí eu criei um evento do ato. Eu pensei: 'vamos criar o evento do ato no Facebook e vamos ver o que acontece. Vamos ver se tem adesão, eu vou colocar nos grupos e vamos ver o que acontece'. E foi daí que surgiu a organização da manifestação do primeiro turno. Porque daí, o que que aconteceu? Ao mesmo tempo que estava acontecendo o evento em Paris, estes atos estavam sendo criados em outras partes do mundo. A gente se conectou e isso é uma das coisas mais interessantes que aconteceu; foi articulação internacional (MARIANA SCHIMITZ, em entrevista à autora e ao autor em 23/10/2019, via Skype).

Mariana se refere à rede digital que conectou as organizadoras dos atos em diferentes cidades do mundo. Tessitura tramada por Luciana Kornalewski e Ana Cláudia Dias, que de Nova lorque acionaram todas as organizadoras das manifestações fora do Brasil contra Bolsonaro, responsáveis também pela criação da arte gráfica que unificou imageticamente o movimento no exterior, observada na Figura 1.

\footnotetext{
${ }^{3}$ O Movimento de mulheres contra Bolsonaro chamou atenção da imprensa nacional e internacional, o que inclui, com especial interesse para o nosso artigo, a mídia francesa de grande circulação nesse país, como o jornal Le Monde.

${ }^{4}$ Para essas autoras, opondo-se ao mito da neutralidade, a perspectiva dos saberes situados implica, em primeiro lugar, uma postura ético-política que reconhece que toda produção científica parte de uma posição situada nas relações de poder. Em segundo lugar, essa perspectiva privilegia a posição de grupos que se encontram social e politicamente minorizados, como as mulheres (apesar de mais numerosos que aqueles dominantes, como os homens), pois compreende que tal posição fornece um ponto de vista epistemologicamente favorável para perceber e, ao mesmo tempo, desconstruir os mecanismos que alimentam a dominação. Nessa perspectiva, a dita neutralidade tenderia a beneficiar a manutenção do status quo, que preserva a posição de poder dos grupos dominantes. Outrossim, um saber ancorado na experiência, por exemplo, de mulheres cis ou trans, de minorias raciais, de sexo e gênero e/ou de mobilidade reduzida que produz uma objetividade corporificada (reivindica uma posição, um corpo), que é diferente de um subjetivismo ou de uma neutralidade universal e abstrata. Esse saber é feminista na medida em que contribui ao empoderamento de tais grupos.

${ }^{5}$ Iniciado pela rede social digital Facebook, a partir da criação, no dia 30 de agosto de 2018 , do grupo apartidário "Mulheres Unidas Contra Bolsonaro", o movimento ganhou as ruas em ato que culminou no dia 29/09/18, como mencionado acima. Em outubro do mesmo ano, o grupo alcançou 2,8 milhões de adesões (e contava com 3,7 em 06/1 1/18) via Facebook e a \#elenão disseminou-se em postagens em diferentes redes sociais digitais. Desde sua criação, até o momento, o grupo foi duas vezes invadido por hackers.
} 


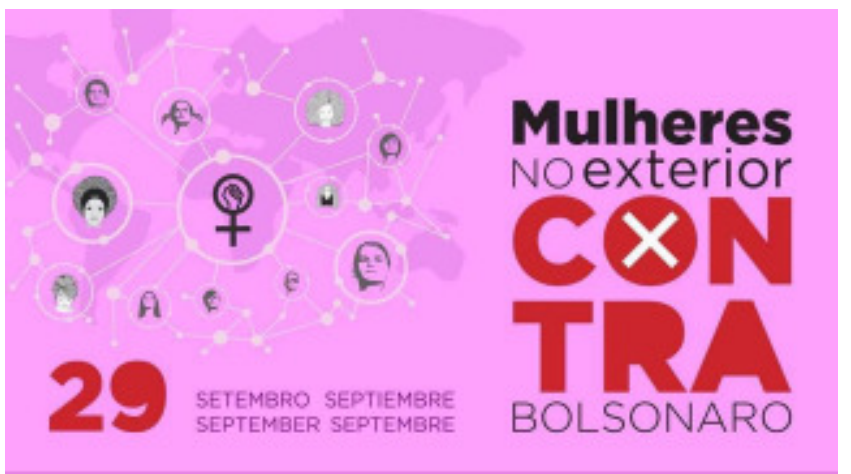

Figura 1 - Imagem de capa do evento no Facebook "Mulheres no exterior contra Bolsonaro"

Fonte: https://www.facebook.com/ events/240718269876460/.

\#PraTodoMundoVer A imagem representa a imagem de capa do evento no Facebook "Mulheres no exterior contra Bolsonaro", tem formato retangular, e carrega as cores lilás, cor oficial da luta feminista, em duas tonalidades, o vermelho, preto e branco. Do lado esquerdo do panfleto digital está o mapa-múndi em lilás mais forte e sobre ele linhas brancas formam fios que conectam rostos femininos circundados em branco. No centro, o continente africano, e sobre ele, o símbolo que se universalizou nos anos de 1960, do movimento feminista. As teias conectam, ao mesmo tempo, o passado recente em que "o pessoal" se mostrou "político", ao presente, quando, por meios digitais, mulheres de diferentes classes, cores de pele, idades, origem regional e religiosa se uniam em torno de uma palavra de ordem. Abaixo do mapa, com recuo à esquerda, aparece o número 29 em vermelho e, ao lado, em duas linhas, com fontes menores, a palavra setembro, escrita em lilás, em quatro idiomas. À direita do mapa, há cinco linhas. Na primeira linha, aparece a palavra Mulheres em destaque preto. Na segunda linha, no exterior, também em preto. Na terceira linha, em vermelho, a primeira sílaba da palavra contra, con, em vermelho, com o preenchido em vermelho e um xis branco em cima. Na quarta linha, aparece a sílaba final da palavra contra, tra, também em vermelho. Na última linha, aparece a palavra Bolsonaro em fonte preta e em letras maiúsculas.

As palavras nos unem e o silêncio nos separa, priva-nos da ajuda, da solidariedade ou da simples comunhão que a fala pode solicitar ou provocar. Certas espécies de árvores espalham sistemas subterrâneos de raízes que interligam os troncos individuais e entrelaçam as árvores num conjunto mais estável, mais difícil de ser derrubado pelo vento (Rebecca SOLNIT, 2017).

A citação acima bem poderia ser uma espécie de briefing para o material gráfico das manifestações contra Bolsonaro no exterior. Ela compõe o capítulo intitulado "Uma breve história do Silêncio", que abre a primeira parte do livro A Mãe de Todas as Perguntas: reflexões sobre os novos feminismos (2017), da escritora feminista Rebecca Solnit. Muitas mulheres brasileiras começaram a quebrar silêncios. "E então, quando as palavras rompem o indizível, o que era tolerado numa sociedade às vezes passa a ser intolerável” (SOLNIT, 2017).

Há pelo menos duas décadas o indizível, como parecia o próprio termo "feminismo", passou a reverberar nas redes e nas ruas do Brasil. Houve uma flagrante inflexão nas pautas feministas no cenário nacional (Gustavo VENTURI; Tatau GODINHO, 2010) que veio se avolumando desde o início deste milênio com a consolidação do projeto democrático nacional, o amadurecimento de movimentos sociais identitários como aqueles que lutam por direitos sexuais, raciais e de gênero e a governos mais afeitos às demandas de segmentos historicamente subalternizados.

Some-se a esse cenário a intensificação do uso e acesso às mídias digitais. Em 2015, a Pesquisa Nacional por Amostra de Domicílios (PNAD) empreendida pelo Instituto Brasileiro de Geografia e Estatística (IBGE, 2016) constatou que cerca de $50 \%$ da população brasileira possuía acesso à internet por meio de computadores e/ou celulares de uso pessoal. Em 2016, a pesquisa sobre o Uso das Tecnologias de Informação e Comunicação no Brasil (TIC Domicílios) realizada pelo Centro de Estudos sobre as Tecnologias da Informação e da Comunicação (CETIC), constatou que essa percentagem aumentou, alcançando a marca de aproximadamente $60 \%$ da população brasileira com acesso à internet. O estudo Digital in 2018 Global Overview registrou um novo aumento, passando para $66 \%$ da população brasileira com acesso à internet (CETIC.BR, 2019).

Assim, na entrada maior nas redes sociais digitais como Facebook, Twitter e Instragram, por meio das quais usuárias/os se tornam produtoras/es de conteúdo e replicadoras/es de discursos diversos, estão os que podem ser associados a temas das agendas feministas, como a descriminalização do aborto, direitos iguais no campo trabalhista, somados a uma flagrante ampliação de vocabulário político por meio do qual comportamentos masculinos antes naturalizados ou silenciados passam a ser questionados e denunciados.

"Novos reconhecimentos exigiam uma nova linguagem, e o feminismo cunhou uma imensidão de termos para descrever as experiências individuais que passaram a sair dos seus esconderijos", pontua Solnit (2017, p. 18 [de 89, Kobo]), referindo-se a outro contexto e a outro momento de amadurecimento dos feminismos, as décadas de 1960 e 1970, nos Estados Unidos. Aqui, nos anos 2000, vimos termos como "heteronormatividade", "heterossexualidade compulsória", "empoderamento feminino" se somarem ao léxico político que mobiliza palavras como homofobia, 
lesbofobia, transfobia, transfeminismo, enquanto feminismo, machismo, assédio sexual apareceram nas redes sociais digitais acompanhadas de hashtags como \#meuamigosecreto, ${ }^{\circ}$ \#meuprimeiroassedio, ${ }^{7}$ alcançando status de trendtopics (assuntos mais citados) nas redes, de forma que muitos temas discutidos nesses ambientes digitais informam e pautam a mídia massiva, ampliando, desta forma, seu alcance. A campanha \#meuprimeiroassedio, iniciada pelo Twitter, foi notícia na grande mídia, ganhando as páginas da revista Época (Marina CARUSO, 2015), do jornal EI País Brasil (Marina ROSSI, 2015), para ficarmos com apenas dois exemplos. Os silêncios se tornavam audíveis.

"Neste cenário, destaca-se a organização de diversos coletivos de jovens feministas, que emergem como um segmento específico dentro do movimento, indicando que o feminismo continua relevante para as novas gerações, ainda que objeto de disputas", afirmam Carla Gomes e Bila Sorj (2014, p. 434) em artigo que remonta à história recente da inflexão das discussões feministas no País. Esta relevância ecoa em plataformas da internet, como as já citadas aqui. Transformações políticas que se refletem em mudanças culturais e possibilidades concretas de acesso às mídias digitais por mulheres, como registram Carolina Ferreira (2015) e Graciela Natanshon (2013).

No Brasil, a diferença entre homens e mulheres no acesso à internet tem diminuído nos últimos anos. Em 2009 eram 37,5\% de mulheres e 38\% dos homens entre 15 e 74 anos acessando a internet (IBGE, 2009, apud NATANSOHN, 2013), uma diferença de 0,5\% dos acessos de homens sobre os das mulheres (NATANSHON, 2013). Além disso, segundo essa análise, o número de brasileiras usuárias da rede cresce mais que o dos homens e, quanto maior a idade, maior são as diferenças em favor das mulheres. A Pesquisa Nacional por Amostras de Domicílio (PNAD) de 2013 mostrou que a proporção de internautas no país passou de $49,2 \%$, em 2012 , para $50,1 \%$, em 2013 , do total da população, no qual as mulheres representam 51,9\% deste número (IBGE, 2013, apud FERREIRA, 2015, p. 206).

Nesse contexto, as masculinidades dominantes, a heterossexualidade como norma e os binarismos de gênero foram desafiados, gerando reações que vieram de diferentes setores: dos religiosos aos partidários, culminando em uma onda conservadora que tomou o país após o impeachment da presidenta Dilma Rousseff, em agosto de 2016. Rousseff enfrentou desde a campanha eleitoral às provocações da imprensa sobre sua capacidade para o cargo, não só por ser mulher, mas, mais grave que isso, por não ser uma mulher que atendia a uma expectativa de feminilidade dócil, subordinada, cordata, tutelada por um homem, o que se traduzia até mesmo no seu corte de cabelo e modo de se vestir.

Consideramos que retomar de forma um tanto impressionista esse cenário recente de (re)articulação das vozes de mulheres é importante para seguirmos contando a história que viemos aqui contar, por isso, reservamos uma seção para pensar como alianças de mulheres foram sendo articuladas no campo político. Alianças que não estiveram amarradas às suas localizações, para usarmos os termos de Judith Butler em seu diálogo com Hannah Arendt: "[n]a verdade, a aliança faz surgir essa própria localização, altamente transponível" (BUTLER, 2019, p. 82), exigindo o espaço do aparecimento, da voz, de conexões. É na relação com o poder que as resistências surgem (BUTLER, 2018). É sobre o surgimento do movimento em questão como articulação de resistências de mulheres contra modelos opressivos de masculinidades que versa a discussão a seguir.

\section{O movimento \#elenão e o "Trump tropical"}

Publicitária, ativista, mulher negra e nordestina da periferia de Salvador, na Bahia, Ludimilla Teixeira tornou-se conhecida durante as disputas presidenciais brasileiras de 2018 ao criar no Facebook o grupo "Mulheres Contra Bolsonaro", ${ }^{8}$ o qual potencializou o uso da hashtag \#elenão. A hashtag - simbolizada pela cerquilha - cria indexadores compostos por palavras-chave que organizam o tema em espaços virtuais e, mais recentemente, tem sido um potente instrumento na luta política feminista, como discute Fernanda Freire (2016).

"Ele" é Jair Bolsonaro, então candidato à presidência da República. O "não" procurava sintetizar uma série de recusas de muitas mulheres brasileiras ${ }^{9}$ às declarações machistas, falocêntricas, LGBTfóbicas e racistas enunciadas por Bolsonaro enquanto candidato. Em entrevista à Claire Gatinois (2018a; 2018b), enviada especial do jornal francês Le Monde a Salvador, Ludmilla

\footnotetext{
${ }^{6}$ Campanha difundida por meio do Twitter e do Facebook, em novembro de 2015, que visava à denúncia de comportamentos machistas intimidatórios e agressivos. A mesma foi uma iniciativa do coletivo Náo Me Khalo. ${ }^{7} \mathrm{O}$ site feminista Think Olga, que também lançou a campanha Chega de Fiu-Fiu, foi responsável por propor que meninas, jovens e mulheres fizessem seus depoimentos de desabafo nas redes sociais digitais falando de situações que hoje elas percebiam como assédio sexual e de como isso marcou suas vidas.

${ }^{8} \mathrm{O}$ Grupo criado por Ludimilla Teixeira no Facebook tornou-se um fenômeno noticioso, dado o crescimento rápido de adesões. Em um mês o grupo chegou a 3,8 milhões de membros. A página sofreu ataque cibernético em 16/09/18, o que gerou ainda mais repercussão na mídia. A recuperação da página deu-se no mesmo dia. Em fevereiro de 2020 o grupo, agora com o nome de "Mulheres Unidas com o Brasil", contava com 2.424.238 membros.

${ }^{9}$ Como iremos mostrar, as falas de Bolsonaro geraram reações em mulheres, feministas ou não, mundo a fora. Nosso foco será a França. Vale destacar a adesão das cantoras norte-americanas Madonna e Cher ao \#elenão.
} 
Teixeira revelou que a motivação para a abertura do grupo foi gerada por intensa inquietação frente à ascensão da popularidade de Bolsonaro em um país no qual, historicamente, as mulheres estiveram alijadas da arena pública como agentes políticas capazes de se fazerem ouvir e serem levadas a sério em suas demandas por simetria de gênero.

As declarações de cunho misógino foram registradas em diferentes momentos da carreira política do capitão reformado do exército brasileiro, Jair Bolsonaro. Em 2003, e novamente em 2014, em discussão no parlamento, com a deputada Maria do Rosário, do Partido dos Trabalhadores (PT), Bolsonaro disse à deputada: "não te estupro porque você não merece". Episódio que lhe rendeu uma condenação num processo por incitação ao estupro e uma queixa-crime por injúria. ${ }^{10}$ Em 2011, ainda um desconhecido, mas já polêmico como deputado, Bolsonaro foi entrevistado por Preta Gil, artista filha de Gilberto Gil, no programa de televisão CQC. " Quando inquerido sobre sua reação se um de seus filhos se relacionasse com uma mulher negra, respondeu que "Preta, eu não vou discutir promiscuidade com quem quer que seja. Eu não corro esse risco. Meus filhos foram muito bem educados e não viveram em ambiente como lamentavelmente é o teu". Também na TV, em 2016, declarou à Luciana Gimenez, apresentadora do Super Pop, ${ }^{12}$ que não empregaria uma mulher com mesmo salário de um homem. Além de ter afirmado, em 2017, durante uma palestra no Clube Hebraica, em São Paulo, que "eu tenho cinco filhos. Foram quatro homens, a quinta eu dei uma fraquejada e veio uma mulher".

Bolsonaro tem uma forma firme e direta de falar, o que lhe angariou apoio e simpatia, pois, para muitos, sua postura era sinal de autenticidade e de coragem, mas também provocou a rejeição de boa parte do eleitorado feminino, o qual representa $52 \%$ do eleitorado (TRIBUNAL SUPERIOR ELEITORAL, 2018). Segundo pesquisa do DataFolha, em 25/10/1 8 (G1 PORTAL DE NOTÍCIAS, 2018 a), isto é, a três dias do segundo turno eleitoral, a intensão de voto feminino ao candidato do PSL estava tecnicamente empatada com a do PT. Ver também a pesquisa do IBOPE, em 24/10/2018 (G1 PORTAL DE NOTíCIAS, 2018b). Dentre essa fatia de eleitoras, um número expressivo de mulheres começou a manifestar recusas à candidatura de Bolsonaro. O que começou de forma espontânea, transformou-se em um movimento que cresceu durante o processo eleitoral, mas que teve desdobramentos imprevistos, como a manifestação de mulheres pró-Bolsonaro chamada \#elesim (Vera FRANÇA, 2018), como uma resposta aos eventos mundiais do \#elenão.

As falas polêmicas sobre questões raciais, relações de gênero e orientação sexual somaramse a um estilo populista e ultraliberal, o que levou a imprensa francesa de direita, mas não apenas ela, a chamá-lo de "O Trump Tropical", como, por exemplo, Adrien Jaulmes (2018) para o Le Figaro. O Brasil não é os Estados Unidos, é óbvio dizê-lo, mas talvez o óbvio seja a nossa matéria-prima quando temos à frente da nação um homem que encarna discursos violentos, mas vistos como recursos emergenciais e efetivos, uma espécie de "solução final" para o bordão da "luta contra a corrupção". Uma corrupção que avançaria as trincheiras do poder, a impessoalidade do Estado, para o seio das famílias e das relações íntimas, por isso, ela foi difundida como sendo também moral. Daí pensar que Bolsonaro é uma espécie de versão latina do presidente americano talvez seja manter o olhar crítico marcado pela percepção colonialista que nos faz remedos do Sul Global, quando, de fato, temos uma realidade que nos singulariza na trama geocultural.

Ao contrário de Trump, Bolsonaro não é um políitico "fora do sistema"; esteve no poder legislativo nas últimas quase três décadas, enquanto o atual presidente norte-americano tem seu histórico marcado pelo seu envolvimento com o mercado e com a mídia de entretenimento. Citamos aqui apenas esse aspecto, a fim de sublinharmos que esta diferença de origem fala mais da sociedade onde cada um se constituiu como liderança, do que de suas próprias biografias. O que os une, apesar das distâncias, está para além das marcas nacionais, mas enredado em uma trama transnacional na qual "discursos abertamente autoritários, anti-humanistas e antidemocráticos" vêm sendo legitimados "pelo voto popular, partidos políticos e/ou lideranças populistas" (Luciana BALLESTRIN, 2018, p. 149).

Poucos meses depois das manifestações parisienses embaladas pelo \#elenão, no âmbito de uma entrevista, o sociólogo francês Éric Fassin fala sobre a atualidade da política brasileira (Larissa PELÚCIO; Diego PAZ, 2019). Na ocasião, Fassin, que também é professor nos Departamentos de Ciências Políticas e de Estudos de Gênero da Universidade de Paris 8, comentou sobre a díade Trump-Bolsonaro.

\footnotetext{
${ }^{10}$ No dia 23 de maio de 2019, a juíza Tatiana Medina, de Brasília, condenou Bolsonaro a pagar uma indenização à deputada Maria do Rosário. Além disso, segundo a condenação, ele deveria veicular publicamente um pedido de desculpas no formato de nota de retratação. Bolsonaro publicou essa nota em sua conta do Twitter, apenas no último dia de prazo dado pela juíza e justificando sua conduta pelo "calor do momento", o que ele havia falado duas vezes. Após a publicação, a deputada usou a mesma rede social para comemorar o que ela chamou de "uma vitória pela dignidade de todas as mulheres brasileiras".

11 O "Custe o que Custar", mais conhecido como CQC, foi ao ar semanalmente pela extinta Rede Bandeirantes de Televisão entre os anos de 2015 a 2018.

12 O Super Pop é um programa de variedades, que está no ar pela Rede TV desde 1999.
} 
Por que Trump quer afirmar seu sexismo? Por que Bolsonaro quer acrescentar de alguma forma, nessa encenação permanente de uma masculinidade heterossexual triunfante? [...] Porque precisamente a ordem sexual é importante. É assim que se ganharam eleições. Esta não é uma questão periférica, não um problema para as minorias, as questões das minorias afetam a ordem social. Nós já sabíamos, mas agora está claro que eles estão em jogo na democracia. [...] Eu acredito que tanto Trump, quanto Bolsonaro incorporam, e quando eu digo "incorporar" é realmente fisicamente, um tipo de masculinidade que foi desafiada (p. 9).

Fassin coloca como esses "personagens" utilizam a ordem tradicional do gênero (não como a diferença entre os sexos, mas como um sistema privilegiado para significar relações de poder que produzem essa diferença), para mobilizar um eleitorado que vê na figura do homem que encarna essa masculinidade triunfante idealizada como a solução para "os problemas na política", que no Brasil tem sido nomeada de corrupção.

Eles representam o papel daquele "homem branco furioso" (angry white men), para utilizar o termo do sociólogo Michael Kimmel (2013), que vocifera contra as minorias políticas, para lhes colocar em "seus lugares", mas também para reintroduzir no centro do poder a identidade que eles pretendem representar, o masculino. De acordo com Marie-Cécile Naves (2018), que analisa o caso de Donald Trump, a obsessão desses "homens brancos furiosos" é aquela, frequentemente situada no centro de seus projetos políticos, do restabelecimento de um modelo de sociedade construído sobre o fulcro da masculinidade. Contudo, não qualquer masculinidade. A masculinidade valorizada nesse contexto é aquela que carrega os atributos de um homem branco, heterossexual, virilizado, pouco escolarizado (ou portador de um saber prioritariamente técnico a intelectual), desprovido de afetividade e, particularmente, no caso brasileiro, militarizado.

Essas figuras políticas emblemáticas manejam com a retórica antifeminista da crise da masculinidade como estratégia antifeminista (Francis DUPUIS-DÉRI, 2012; Sérgio SILVA, 2006), a fim de obter vantagens no debate público. Porque estimam esse modelo de masculino ameaçado, irão se esforçar em reafirmá-lo. A maneira como o encarnam é, contudo, exagerada, teatralizada e caricaturada. Enfim, se a comparação produzida pela mídia é problemática, ela serve para reconhecermos que o gênero é o eixo do embate em muitos dos jogos políticos da atualidade, e uma estratégia de muitos líderes populistas que buscam incitar seu eleitorado fiel para obter capital político.

Ao encarnar a virilidade bruta, sem vergonha dos arroubos machistas e homofóbicos, Bolsonaro era recusado ali por ser um tipo de vingador do passado, que devolve os privilégios masculinos, heterossexuais e brancos supostamente ameaçados desde o início deste milênio, quando começamos a assistir a mudanças significativas no cenário nacional relativas, justamente, a direitos sexuais, relações de gênero e raça. Para algumas pessoas essas transformações pareceram o fim do mundo, quando, na verdade, se tratava de o fim DE um mundo. Retomar essa cronologia, acreditamos, nos ajuda a ir das ruas do Brasil à Place de la République, em Paris.

\section{O lado B do Brasil}

Nosso recorte temporal abrange o ano de 2011 , quando Dilma Rousseff é eleita para seu segundo mandato como a única mulher a ocupar a presidência da República, até o fim daquele verão europeu, em que as eleições presidenciais de 2018, no Brasil, levaram centenas de brasileiras e brasileiros às ruas de Paris. Comecemos, então: em 2011, nós tivemos pela primeira vez uma mulher na presidência da República. Isso não é pouco em um país estruturalmente machista como o Brasil e no momento já temos condições empíricas e analíticas para ler a misoginia que esteve implicada no processo de impeachment de Rousseff (Elen Cristina GERALDES et al., 2016).

Ainda em 201 1, ocorreu em São Paulo a primeira edição da Marcha das Vadias, quando mulheres se organizaram pelo Facebook, Twitter e blogs (Carla GOMES; Bila SORJ, 2014). Uma pesquisa realizada pela Fundação Perseu Abramo (VENTURI; GODINHO, 2010), publicada em 2010, mostrava um crescimento do feminismo no Brasil. Entre 2001 e 2010, o número de mulheres que se assumiam feminista passou de $21 \%$ para $31 \%$. Era possível ver estas porcentagens atuando nas ruas a partir da organização crescente de mulheres jovens como em 2015, quando milhares vão às ruas contra um projeto de lei que visava à criação de novas regras para a interrupção da gravidez de mulheres vítimas de estupro, comprometendo direitos relativos a aborto legal. Este movimento se chamou "Fora Cunha", em referência ao então Presidente da Câmara dos Deputados, Eduardo Cunha, quem propôs a lei - como fora descrito nas matérias publicadas em Portais como G1 (Daniel SILVEIRA, 2015), Folha de São Paulo (Ronald LINCOLN JR; Eduardo GERAQUE, 2015) e no periódico El País (María MARTíN; ROSSI, 2015).

Do nosso ponto de vista analítico, a base política do que viria a ser o movimento \#elenão, movimento de mulheres brasileiras contra Bolsonaro, começava a se formar naquele momento.

Assim como a ideia de reagir aos discursos homofóbicos, misóginos e racistas que marcaram a carreira política de Bolsonaro, já estava ganhando voz com a Marcha das Mulheres Negras, que teve sua primeira edição em 20 de novembro de 2015, em Brasília, e se espraiou pelo País nos 
anos subsequentes. O que queremos dizer é que um vocabulário de enfrentamentos e denúncias estava sendo gestado e experimentado no coletivo, por muitas mulheres no Brasil dos últimos 20 anos. Década que começou assistindo à primeira Marcha das Margaridas, movimento que uniu mulheres do campo em torno da luta pela terra. O nome de Margarida Alves batiza a marcha, uma homenagem à militante pelos direitos de quem trabalha no campo, pela educação e pela agricultura sustentável, assassinada em 1983 por sua atuação política.

Um outro dado importante para entender este cenário que estamos desenhando aqui de forma um tanto impressionista refere-se ao campo dos direitos sexuais, sobretudo a visibilidade que estas pautas vinham alcançando para além do ativismo e das ações do Estado. Em 201 1, o número de participantes da Parada da Diversidade de São Paulo chegou ao recorde, ainda não superado, de 4 milhões de pessoas. Foi também em 2011 que as uniões estáveis entre pessoas do mesmo sexo passam a ser legalmente reconhecidas pelo Supremo Tribunal Federal. Dilma Rousseff, que havia assumido seu segundo mandato naquele ano, tomou como uma de suas primeiras medidas o veto ao "kit anti-homofobia", material didático que visava à promoção de uma educação inclusiva baseada no respeito às relações de gênero e à diversidade sexual. A Decisão de Rousseff foi uma resposta tímida e assustada à pressão dos membros do Congresso ligados às igrejas católicas e evangélicas que julgaram o material obsceno e sexualizante. À frente desta campanha difamatória estava Jair Bolsonaro, até então um obscuro membro do Congresso Federal.

Somou-se a esse discurso a proteção "à família" e a demonização dos feminismos. Usada, inclusive, para esvaziar a potência do movimento \#elenão, em uma retórica tão poderosa que muitas pessoas de esquerda passaram, elas também, a atribuir ao movimento o crescimento de Bolsonaro; ao invés de examinar como os discursos dos cruzadistas antigênero criaram polarizações entre mulheres "boas" e as "más", em um ambiente político no qual se buscou exatamente alianças e não polaridades.

Voltemos a 2004, ano em que se criou a Secretaria de Educação Continuada, Alfabetização, Diversidade e Inclusão (SECADI), que acolheu o programa de formação continuada para professoras e professores do ensino básico chamado Gênero e Diversidade na Escola. Os dados da Pesquisa Nacional por Amostra de Domicílios, o PNAD, de 201 1, mostrou que houve ampliação expressiva do acesso ao ensino superior por parte de estudantes pretos e pardos - de fato esse número triplicou ao longo da década. O fim DE um mundo, como mencionamos há pouco, parecia estar se aproximando de forma acelerada.

A resposta a 2011 , esse ano de inflexão de lutas, começa a ganhar força em meados de 2013, com as chamadas Jornadas de Junho, um movimento que se inicia de forma popular, associado a pautas de esquerda e que não tardou a ser capturado pela "nova direita" (Marina AMARAL, 2016; Esther SOLANO, 2019). É nessa cena que nasce o Movimento Brasil Livre. Livre de tudo que incomodava a elite branca, que nunca engoliu o sistema de cotas raciais para o acesso às universidades públicas; livre das políticas econômicas redistributivas como o Bolsa Família, programa que a classe média também não digeriu, mas mesma classe média que se indignou quando se votou a proposição de emenda constitucional das Domésticas. Lembremo-nos de que Bolsonaro, que era deputado à época, se declarou orgulhoso de ter votado contra essa decisão.

Paralelamente a essas mudanças, tínhamos que enfrentar as consequências da política econômica conciliatória do governo Dilma. Uma política que não conseguiu enfrentar as expectativas das classes populares provocadas pela forte incitação ao consumo vinda dos governos Lula. Não foi difícil, então, para os opositores de Dilma, associarem a crise econômica à corrupção, revelada pelos escândalos da Operação Lava-Jato.

De forma que a cólera contra a corrupção política foi associada à ideia de corrupção moral supostamente promovida por movimentos como o feminista, raciais e LGBT+, associados, por sua vez, às políticas do PT. ${ }^{13}$ A corrupção moral, segundo os setores conservadores, estaria igualmente presente nas escolas públicas, onde os professores teriam se tornado doutrinadores ideológicos. De forma que, em 2014, nós começávamos a assistir à criminalização da educação ao Brasil. O "gênero", como um objeto de estudo, tem sido construído como uma ameaça ao autoritarismo nacionalista e religioso. O populismo de direita depende do racismo, da misoginia e da homofobia para consolidar seu ódio como peça estratégica fundamental de suas ações políticas. Foi assim que a "ideologia de gênero" se tornou o olho do furacão que movimentou toda uma rede complexa de significados, tornando-se um operador de forças políticas.

A antropóloga brasileira Isabela Oliveira Kalil (2018a; 2018b) mostra, a partir de dados colhidos em pesquisas etnográficas feitas em manifestações de rua a favor do impeachment de Dilma, bem como na manifestação contrária à presença da filósofa Judith Butler no Brasil, em 2017 , como a categoria "ideologia de gênero" mobilizou um conjunto de termos que deveriam ser

\footnotetext{
${ }^{13}$ Esta associação tem se mostrado persistente. Em fevereiro de 2020, ao defender a campanha pela abstinência sexual lançada pelo ministério de Damares Alves, Bolsonaro declarou: "Essa liberdade que pregaram ao longo (das gestões) do PT todo, que vale tudo, se glamouriza certos comportamentos que um chefe de família não concorda, chega a esse ponto, uma depravação total. Não se respeita nem sala de aula mais" (sic).
} 
combatidos - como a transexualidade, o feminismo, os temas LBGT+, o comunismo, o socialismo, as travestis, homossexuais, bissexuais, os não binários, os partidos de esquerda, as políticas voltadas para populações originárias, a pluralidade de pensamento, a diversidade cultural, a laicidade, as ciências sociais, os intelectuais, o aborto, os direitos humanos, as religiões de matriz africana, o movimento sem terra, a sexualidade, as artes, temas associados à proteção ambiental e até mesmo a ONU.

Foi assim que, em 2017, Judith Butler se tornou alvo de gritos como "queimem a bruxa", proferidos por manifestantes contrários àquilo que tomaram como sendo as ideias de Butler: incentivo à pedofilia, conversão de crianças em homossexuais e o anulamento de normas que regulam sexo e gênero, como se isso fosse de fato possível em termos antropológicos e sociológicos. Durante a campanha eleitoral de 2018 , Bolsonaro reavivaria essa discussão tornando o "kit anti-homofobia" uma das mais potentes fake news de sua bem-sucedida máquina digital de produção de "verdades".

Nas palavras de Achille Mbembe (2017), se referindo aos inimigos fantasmáticos, esses podem ser acionados mesmo nos contextos democráticos e funcionam com intuito de demonizar o Outro mais espectral que real.

Esses inimigos com os quais nenhum entendimento é possível ou desejável aparecem em geral sob os traços de caricaturas, clichés e estereótipos. Caricaturas, clichés e estereótipos Ihes concedem uma presença figural, essa forma de presença que, por sua vez, só faz confirmar o tipo de ameaça (ontológica) com a qual eles nos assombram (MBEMBE, 2017, p. 76).

É Mbembe, ainda, que propõe que a instalação do medo é um elemento central nesse ambiente de inimizades. De fato, ele cunha o conceito de "sociedade de inimizade" para descrever o clima de desgaste das democracias contemporâneas, vampirizadas pelo neoliberalismo que precarizou o trabalho, exacerbou a competição, inflou a meritocracia e "terceirizou" os custos da ruína que ele promoveu às políicas inclusivas.

Achille Mbembe não faz referência ao Brasil nessas análises, mas bem poderia tê-lo feito. $O$ Brasil, contrário aos projetos de inclusão social, e orgulhoso de sê-lo, revelou seu "lado B". Não por acaso, nem subitamente, apareceu Bolsonaro arrebatando os votos dos "cidadãos de bem" (Linda GORDON, 2017) 7) contrários "a tudo isso que tá aí", um termo tão vago quanto abrangente, que em sua amplitude abrange do antipetismo ao medo do fim da família, passando pelo pânico da promoção da homossexualidade nas escolas (KALIL, 2018a). Contra "tudo isso que tá aí", nós parimos um Messias e colocamos em risco uma série de direitos duramente alcançados. Diante dos retrocessos anunciados, mulheres foram se articulando pelas redes digitais em um movimento que cruzou fronteiras e que teve na hashtag "ele não" seu ponto de convergência, mesmo entre as divergências, como se passou no movimento em Paris.

Na Praça, quase uma metonímia para se falar da arena clássica dos debates políticos, mulheres assumiam o protagonismo na luta por assegurar avanços da pauta dos direitos sexuais e de gênero, temas que foram fortemente politizados nas últimas décadas no Brasil.

\section{Mulheres em praça pública}

Em 29 de setembro de 2018, seguindo a agenda de outras cidades no mundo e do Brasil, a Place de la République, espaço histórico de atos políticos em Paris, foi palco do "Mulheres no exterior Contra Bolsonaro". Em Paris, onde o \#elenão fora traduzido em \#paslui, o ato somou-se à convocação organizada pelo Facebook a partir do grupo on-line "Mulheres Contra Bolsonaro". No Brasil, órgãos da grande imprensa noticiaram atos em mais de 40 cidades e contabilizaram outras manifestações em diversos locais no exterior, por exemplo (FOLHA DE SÃO PAULO, 2018).

Eu tinha reservado a Praça da República pras duas horas até as quatro. E elas tinham reservado das quatro até as seis [Naná se refere a Mariana e Carol]. Eu disse 'olha, eu vou chegar cedo'. E aí ficamos eu e a Mariana, graças a ela é que teve esse negócio, porque ela reuniu no Face todo o pessoal! Marcou a hora e o pessoal deu dinheiro a ela pra comprar o material e a gente fazer. E eu levei o material que eu fiz. Que eu não ia convidar essas sectárias pra fazer material, eu fiz sozinha. Aí eu fiz, levei. A gente marcou a uma e meia na Praça da República e aí botamos os negócios tudinho lá, fizemos, pintamos os cartazes. Eu, ela e a filha dela. Nós três na Praça da República fizemos tudo. E aí foram chegando, chegando, chegando e aí fizemos! E deu umas 400, 500 pessoas na Praça. Não foi muita gente, mas foi legal e deu margem... foi aberto. Quem queria falar falava (Naná, em entrevistas à autora e ao autor, em Paris, 1 de fevereiro de 2019).

\footnotetext{
${ }^{14} \mathrm{O}$ termo, quanto à historiadora Linda Gordon, recupera o título do periódico Good Citizen, publicado nos Estados Unidos entre 1913 e 1933 pela líder religiosa radical Alma White. Alma Bridwell White (1862-1946) foi uma pastora, bispa metodista estadunidense e fundadora da Igreja da Coluna de Fogo (The Pillar of Fire Church). Conhecida por suas posturas antissemitas e racistas, ela declarava constante apoio à organização supremacista branca Ku Klux Klan, no âmbito de seu periódico mensal Good Citizen.
} 
Foram três horas de ato com microfone aberto, isto é, todas as pessoas que quisessem se manifestar, desde que o tema estivesse relacionado à pauta do ato, poderiam fazê-lo.

Eu estava animando o ato, mas a ideia era deixar todo mundo fazer uso da palavra. Claro, tinha uma lista de pessoas que tinham de falar. Mas era importante que aquelas mulheres que estavam participando pela primeira vez de um ato, que nunca tinha militado nem no movimento feminista, nem em movimento nenhum, que elas ocupassem o espaço delas também (Mariana Schmitz, na entrevista citada acima)

"Todos nós temos nosso mar de palavras não ditas" (SOLNIT, 2017, p. 1-86). Garantir a praça como locus de expressão àquelas que debutavam nos atos foi visto como uma forma de inclusão democrática e de formação política, contribuindo para que as mulheres ali presentes garantissem "o espaço de aparecimento" (BUTLER, 2018, p. 82), aquele que, segundo Arendt, relida por Butler, é onde "apareço para os outros e onde os outros aparecem para mim", como corpo e discurso, um momento de fala "entendida como o exercício corporal e linguístico dos direitos" (BUTLER, 2018, p. 85), o que não costuma acontecer sem disputas e atritos. Esses também são parte da construção do ato político e do exercício político. A ideia de que o feminismo é um bloco de sororidade não é só ingênua, mas guarda uma ponta de crenças de que as mulheres associadas aos feminismos são, elas sim, perigosas socialmente e inocentes politicamente.

Esse espaço de aparecimento não é um local que pode ser separado da ação plural que leva a ele; não está fora da ação que o invoca e o constitui. Ainda assim, se aceitarmos essa visão, temos que entender como a pluralidade que age é constituída. Como uma pluralidade se forma, e quais são os suportes materiais necessários para essa formação. Quem entra nessa pluralidade, e quem não entra, e como essas questões são decididas? (BUTLER, 2018, p. 87).

A pluralidade formada ali incluía mulheres brasileiras emigrantes; entre estas estavam as politizadas, as escolarizadas, as "despolitizadas", as recém "empoderadas", talvez estivessem também as ilegais conectadas pelas redes digitais a partir da recusa à proposta política bolsonarista. Mas havia mais que consensos e convergências, como narraram nossas entrevistadas, e a proposta do "microfone aberto", ainda que bem-sucedida, segundo avaliaram, foi atravessada por disputas de fala, às quais carregam posições estratégicas, como pondera Carolina Giliolli Goos: Se alguém conservador vier falar comigo, eu vou dizer sim 'Lula livre'. Mas ali, naquele contexto... não foi o que se combinou nas 500 reuniões. Foi uma deliberação internacional! Tiramos diretrizes, não foi algo que veio do dia pra noite.

Mariana conta que uma parte das mulheres ligadas a um partido específico chegou antes da hora marcada pelas organizadoras para iniciar o ato sem a presença das demais, conduzindoo a partir de suas pautas particulares e descumprindo o que havia sido decidido coletivamente. Ao serem interpeladas, reagiram, o que chamou atenção de outras manifestantes, estas, francesas, que estavam em grande número também ocupando a Praça para uma reunião de preparação do movimento de mulheres contra violência sexual e assédio chamado Nous Toutes (em português: Todas nós).

Elas fizeram o ato delas [...] nisso chegou esse pessoal que quis sequestrar o ato, chegou a ter um conflito sim, real entre a gente. Daí as outras meninas da organização do comitê oficial chegaram. Teve bate-boca! Foi uma coisa horrivel! Ainda bem que não tinha ninguém! Tava só assim o pessoal da treta mesmo. Daí as francesas chegaram e intervieram na coisa. Elas eram muito mais numerosas que nós. Tinha sei lá... umas duas mil, três mil mulheres no ato delas. E aí a Caroline de Haas [jovem e expressiva figura do feminismo francês] veio falar com a gente e disse 'olha, nós vamos terminar nosso ato mais cedo pra vocês ocuparem a Place de la République. Nós chamamos as francesas para ficarem no ato de vocês para darem apoio ao ato de vocês e aí vocês podem ocupar o centro da praça'. A gente tava assim meio de lado. E foi aí, nesse momento de transição que a mesa virou e a gente conseguiu pegar o ato de volta. E aí a gente teve de realojar e começar oficialmente o ato. Esse conflito foi bem desgastante (Mariana Schmitz, na já citada entrevista).

Por outro lado, foi em meio a tensas negociações, presentes em muitos contextos nos quais se negociam agendas políticas, que apareceu a solidariedade de outras mulheres com 0 Movimento Mulheres Contra Bolsonaro.

"Solidarité avec les femmes brésiliennes"; "Fierté des femmes au corver de toute démocratie" foram os dois primeiros cartazes que vimos ao chegarmos à manifestação que acontecia na Place de la Bataille de Stanligrad, situada na região nordeste de Paris, no $19^{\circ}$ distrito, muito perto do Canal de Saint Martin. Era 20 de outubro de 2018, estávamos a poucos dias da realização do segundo turno das eleições presidenciais no Brasil, uma eleição absolutamente singular, que levou a sociedade brasileira a experimentar seus extremos; na qual as redes sociais digitais tiveram papel decisivo, fazendo com que aquela forma de expressão política que vivenciávamos na praça parecesse tão anacrônica quanto necessária. A ideia de um possível e iminente retrocesso no campo dos direitos sexuais e de gênero mobilizou essas mulheres que também falavam em 
lutar por democracia e direitos humanos. Os companheiros franceses estavam ali também se solidarizando. Havia ainda representantes de diversas associações políticas e partidos locais. ${ }^{15}$

A imprensa local circulava com microfones longos e filmadoras estratégicas entre grupos de Maracatu e Bumba meu boi sobressaiam cartazes escritos em português e francês. "Pas lui"; "\#elenão"; "Fake não"; 16 "Tous unis contre le fascisme" ("Todos unidos contra o fascismo"); "Oui à une humanité adulte, démocratique et paritaire" ("Sim a uma humanidade adulta, democrática e igualitária"). "Marielle, Presente!"17 era um grito constante - o que nos remete ao texto de Isabela Kalil publicado no blog da editora Boitempo em diálogo direto com homens intelectuais de esquerda que apontaram o \#elenão como um erro estratégico da esquerda, mas não de qualquer esquerda, mas daquela intelectualizada, branca e de classe média. Ao "ler" os atos, Kalil alfineta:

É preciso considerar ainda que esses atos são devedores da mobilização de outros eventos de pouca visibilidade como a Marcha das Mulheres Negras, a Caminhada de Mulheres Lésbicas e Bissexuais, a Marcha das Margaridas, a Marcha da Maconha ou outros pequenos eventos de mulheres antifascistas e anarquistas realizados nas periferias. Não menos importante, este movimento \#EleNão expressa indignação com a ausência de respostas em relação ao assassinato de Marielle Franco (KALIL, 2018b).

Quer dizer, o movimento de mulheres foi aquele que, de forma constante e plural, veio construindo pautas políticas nos últimos anos, como retomamos de forma bastante ligeira mais acima. Essas pautas apareceram, em alguma medida, também no ato na Place de la Bataille Stalingrad, onde discursaram mulheres negras, transexuais e aquelas ligadas a partidos que se posicionam como sendo de esquerda. Na Place de la Bataille de Stalingrad agitavam-se bandeiras desses partidos e também bandeiras do Brasil, que serviam ainda de capa para algumas pessoas que a portavam com orgulho: "eles não podem se apropriar de um símbolo nacional, a bandeira do Brasil não pode virar uma propriedade dele", disse um desses jovens que vestia o pavilhão nacional e acompanhava Camila, que havia deixado o filho pequeno com o marido para ir ao ato político.

Havia muita gente jovem, na sua maioria brasileiras/os. As pessoas mais velhas, como as mulheres que seguravam os cartazes em solidariedade às "femmes du Brésil", eram francesas. Como observou uma brasileira, professora universitária aposentada, com quem conversamos durante o evento: "a velha-guarda comunista e socialista, a geração de maio de 68, está conosco. O fascismo é intolerável". A professora somava sua voz a quase mil outras presentes ao "Rassemblement contre le Fascisme au Brésil" ("Ajuntamento contra o fascismo no Brasil").

Nos últimos anos, diversos países de todos os cantos do mundo foram acometidos por uma espécie de nacionalismo de extrema-direita. A lista inclui Rússia, Hungria, Polônia, Índia, Turquia e Estados Unidos. A tarefa de generalizar em torno de tal fenômeno é sempre problemática, já que o contexto de cada país é sempre único. Mas essa generalização é necessária no momento atual (Jason STANLEY, 2018, posição 40 de 2836, Kindle).

Mesmo considerando peculiaridades locais, Stanley traça as linhas de força que se entrelaçam no cenário mundial, conformando o que ele chama de fascismo, mesmo sob o risco de nomear com conceitos pretéritos fenômenos contemporâneos. Segue Santley (2018): "A política fascista inclui muitas estratégias diferentes: o passado mítico, propaganda, anti-intelectualismo, irrealidade, hierarquia, vitimização, lei e ordem, ansiedade sexual, apelos à noção de pátria e desarticulação da união e do bem-estar público" (posição 49). Era disso que falava a professora com quem conversamos naquele dia ali na Place.

As mulheres que entrevistamos estavam bastante preocupadas com as "ansiedades sexuais" que apareciam nos discursos bolsonaristas. "Seu aspecto que mistura violência e gracejo, brutalidade sanguinária e piadismo, não é tanto a rigidez do militar ultradisciplinado, mas traz representada em si a conduta própria à classe dominante brasileira desde os tempos de Machado [de Assis]" (Felipe CATALANI, 2018). O que significa garantir privilégios assegurando-se que as desigualdades estruturais serão preservadas - entre estas estão as de classe, raciais, gêneros e sexualidades. Parece-nos sintomático que o "Kit-gay" tenha sido uma das mais vigorosas notícias manipuladas da campanha de Jair Bolsonaro e que Manuela D'Ávila (PCdoB), candidata à vicepresidência na chapa de Fernando Haddad (PT), tenha sido um dos alvos preferenciais de

\footnotetext{
${ }^{15}$ Autres Brésils, France Amérique Latine, Les Amis du Mouvement des Sans Terre, Femmes Unies Contre Bolsonaro et la Ligue des Droits de l'Homme.

${ }^{16}$ Alusão à difusão, pela campanha do então candidato Jair Bolsonaro, de notícias falsas contra o candidato do Partido dos Trabalhadores, Fernando Haddad, e contra o próprio PT, por meio de aplicativos de comunicação pessoal como o WhatsApp e que, a partir desse recurso, passaram a ser amplamente compartilhados, criando uma potente rede de inverdades bastante convincentes aos olhos de muitos/as eleitores/as.

${ }_{17}$ Marielle Franco, vereadora carioca eleita pelo Partido Socialismo e Liberdade (PSol) assassinada, juntamente com o Anderson Mathias, que dirigia o carro e que foi metralhado por seus assassinos. $O$ crime continua, até a data de fechamento deste artigo, sem solução. Marielle teve sua trajetória de militância construída na favela onde nasceu, era uma mulher negra, ativista dos direitos humanos, feminista e era casada com uma mulher.
} 
difamações acionadas pela rede de notícias fraudulentas, como destacado por Rejane Gadelha e Roberta Kerr (2019) em sua discussão sobre fake news, mulheres e política.

Aquelas movimentações a que assistíamos em Paris não eram apenas de mulheres, mas de todas as minorias políticas que o projeto bolsonarista propunha aniquilar, seja em direitos ou no tocante à própria existência. Como o que aconteceu durante um ato de campanha realizado no Estado do Acre, quando o então candidato Jair Bolsonaro utilizou um tripé para simular uma metralhadora e defendeu "fuzilar a petralhada", em se referindo às/aos apoiadoras/es do Partido dos Trabalhadores. A declaração foi filmada e o vídeo circulou amplamente nas redes sociais e na mídia. Apesar de uma queixa-crime ter sido apresentada, a Procuradoria Geral da República, na figura de Raquel Dodge, disse, em seu parecer ao Supremo Tribunal Federal, que não viu crime nas declarações de Bolsonaro. O ministro do STF Ricardo Lewandowski acompanhou a decisão da PGR e suspendeu a queixa-crime. Fatos que foram relatados na mídia nacional por Letícia Casado e Reynaldo Turollo Jr (2018) e Paulo Saldaña e Turollo Jr (2019).

O \#elenão mobilizou assim milhões de mulheres, mas também de homens (quer fossem trans ou não) heterossexuais, bissexuais ou homossexuais (lésbicas e gays). Não apenas as minorias sexuais e de gênero estavam implicadas, mas também aquelas produzidas dentro das lógicas de dominação de raça e classe. Aquelas/es às/aos quais eram associadas/os a esquerda política eram alvo do discurso de ódio bolsonarista. Na proposição "Mulheres Unidas Contra Bolsonaro", a palavra "mulheres" fala de uma multidão plural, como os feminismos da diferença, pós-estruturalista, interseccional, decolonial e a teoria queer, para citarmos alguns, vêm defendendo há pelo menos três décadas (Adriana PISCITELLI, 2002; Silvana MARIANO, 2005; Juliana GOES, 2019).

As afirmações, por exemplo, de nossa entrevistada Naná ("As novas são muito legais, não são sectárias" ou "... foi aberto. Quem queria falar falava") trazem à ordem do dia uma velha questão no âmbito da teoria feminista, a saber, de quem falamos quando falamos em "mulheres" no feminismo. É nesse sentido que as provocações teóricas da filósofa Judith Butler nos ajudam numa leitura crítica desses acontecimentos e narrativas. A autora, que não se vê "pós-feminista", insiste que sua crítica ao feminismo é interna, como observado por Éric Fassin no prefácio à edição francesa de Problemas de Gênero (BUTLER, 2006b).

Para essa autora, não se trata de colocar em questão "se ainda faz sentido, estratégica ou transicionalmente, fazer referência às mulheres para fazer as reivindicações representativas em nome delas". Pois, para ela, "o 'nós' feminista é sempre e somente uma construção fantasística, que tem seus propósitos, mas que nega a complexidade e indeterminação internas do termo" (BUTLER, 2006a, p. 205). Butler critica a ideia de que a capacidade de agir (agency), ou a capacidade de agir politicamente (political agency), depende da viabilidade e da produção de um sujeito político estável, e, por que não dizer, naturalizado, i.e., discursivamente anterior ao campo cultural que ele articula (BUTLER, 2006a, p. 205-206).

Nesse sentido, apostamos que essa é uma das grandes potencialidades das "Mulheres Unidas Contra Bolsonaro", a de se tornar um ensaio para uma "política de coalizões" (BUTLER, 2006a, p. 36), em que "unidades provisórias" se constituem com base de um objetivo em vista, que, no caso em questão, se traduzia na negação: \#elenão. Um ensaio porque, como insiste Butler, uma política que visa à superação das marcações identitárias não se conforma com a aglutinação de predicados culturais - cor, sexualidade, classe, capacidades físicas - numa identidade situada, que nunca é capaz de dar conta de todos esses (BUTLER, 2006a, p. 206). Todavia, não é a capacidade de aglutinação do termo "mulheres" naquele momento, mas o deslocamento epistemológico que torna possível: compreender a identidade como uma prática (e não como um substantivo), implica compreender que sujeitos são efeitos dos discursos (e não naturalizados) (Idem, p. 206). No vocabulário butleriano, se as identidades não são a descrição de corpos naturais (pré-discursivos), mas se constroem no discurso, o termo "mulheres", no contexto do \#elenão, funciona como uma injunção a um processo de (re)significação de si que faz funcionar uma identidade culturalmente inteligível. Naquele momento, todas e todos eram "mulheres" e todas e todos estavam "contra Bolsonaro".

Todavia, como confirma a autora (BUTLER, 2006a, p. 213), dizer que uma identidade é um efeito não significa que ela seja totalmente artificial, pois "a desconstrução da identidade não é a desconstrução da política", mas, ao invés disso, ela politiza os próprios termos nos quais a identidade é posta. Esse é o caráter iminentemente político das reflexões acadêmicas, que Butler se implicará em reafirmar, colocando-se, ao mesmo tempo e sem hierarquizar as posições, como teórica queer e feminista (BUTLER, 2006b; BUTLER; Irène JAMI, 2009).

Para Butler (2006a), a compreensão da identidade como uma realização discursiva favorece a capacidade de agir politicamente, na medida em que o foco é deslocado da identidade para as práticas de significação (quer dizer, como as identidades são produzidas e ganham um sentido compartilhado culturalmente). 


\section{Afetos, conversas de bar e considerações finais}

Dias após os atos políticos que aconteceram nas ruas, seguimos as "Mulheres no exterior contra Bolsonaro" em um pequeno bar na Rue de Belleville, que marca a linha limítrofe entre o $19^{\circ}$ e $20^{\circ}$ distrito de Paris. Algumas daquelas mulheres que acompanhamos nas manifestações políticas se reuniram na quase madrugada do dia 28 de agosto para seguir a apuração dos votos das eleições de 2018 no Brasil. ${ }^{18}$

Do lado de fora, um totem de papelão com as fotos de Fernando Haddad e Manuela D'Avila, o candidato à presidência pelo PT e a sua candidata à vice-presidência pelo PCdoB, com o qual parte das brasileiras e brasileiros ali presente interagia fazendo selfies. No interior, $O$ aglomerado de pessoas se protegia do frio externo, mas dificultava a circulação e a visualização da TV, suspensa ao fundo do pequeno bar parisiense. Uma pequena multidão se concentrava naquele espaço comprimido. Entre as/os brasileiras/os, havia também algumas/uns francesas/es. O vermelho, a cor da esquerda, que no Brasil havia motivado agressões verbais e físicas durante o período eleitoral, era predominante e hasteado com orgulho.

As conversas vêm em retalhos e as palavras falam de medo, esperança, luta, números referentes às pesquisas recém divulgadas e de resultados das urnas em países onde a eleição já estava encerrada. A sensação é que havia um temor frente à iminente vitória do candidato da extremadireita. A hora avança, os olhares na direção da TV ao fundo, ligada na Rede Brasil, e dos celulares, que atualizavam os resultados a cada 15 segundos, tornam-se mais frequentes. A tensão aumenta. Com as palmas das mãos, sentíamos sobre a pele, o coração umas/uns das/dos outras/os que pulsava acelerado e forte. É então que, às $19 \mathrm{~h}$ no Brasil e às $23 \mathrm{~h}$ em Paris, que com $86 \%$ dos votos apurados, a esperança se definha, pois uma desejada mudança no resultado não era mais possível.

Ainda no interior do bar, as reações são múltiplas: choros, insultos ao candidato ganhador e gritos de "a resistência começou"! Apesar disso, o momento é de emoção, não de ação. Revolta face ao sentimento de impotência. Ansiedade e medo do futuro. Algumas/uns parecem atônitas/ os: não choram, não riem, não falam. A solidariedade se manifesta e pessoas, mesmo que desconhecidas, oferecem e recebem abraços. Uma mulher, pesquisadora e feminista, exprime-se veementemente em alta voz: "eu vivi a ditadura na minha juventude, não é a minha primeira vez, e eu não sou mais a mesma! Ele [Bolsonaro] verá o que Ihe aguarda!".

Como que fora evocado, o "Mulheres Unidas Contra Bolsonaro" revelou a potência das pautas feministas que vinham sendo gestadas desde o início desse milênio no Brasil. Ser "politicamente mulher" naquele ato era, de certa forma, defender um projeto de sociedade que estava ameaçado em vários níveis, fosse nas falas misóginas, na difusão de notícias propositadamente deturpadas sobre educação e direitos ou pela defesa do armamento, em uma sociedade profundamente desigual e estruturalmente violenta, na qual as armas, mais que "bandidos", matam minorias políticas. Ali, na Place de la République, entre cartazes onde estavam inscritos "Ele não. Ele nunca. Ele jamais", travava-se uma disputa de sentidos sobre direitos, democracia e projetos de nação. As bandeiras do Brasil com as inscrições "\#elenão \#paslui \#nothim", na faixa branca onde historicamente se lê "ordem e progresso", eram ícones expressivos dessas disputas.

Passado o primeiro ano do governo Bolsonaro, entramos novamente em contato com as organizadoras e algumas participantes dos atos contra o então candidato à presidência em Paris. Os depoimentos vieram por meio do WhatsApp e Messenger. Nas mensagens escritas e/ou em registro de voz que nos foram enviadas havia um misto de afetações (sentimento de derrota, desilusões, medos) com uma capacidade de fazer leituras racionais da conjuntura.

Estou e estamos adoecidas pela presença de um governo que nos mostra cada dia mais implacável e comprometido com a retirada de direitos, que os desrespeita, que faz chacota com a morte de Marielle, que extermina às claras todo o pensamento que privilegia a democracia! Tudo, absolutamente toda a conduta do governo nos ataca e nos afeta diretamente! Difícil pensar no futuro no Brasil! Difícil pensar que nossos direitos serão mantidos! As condições de trabalho têm piorado muito de forma direta e indiretamente por conta do bolsonarismo! Há publicamente uma política de exterminio e ódio sobre todas nós mulheres, negras, indígenas e sobre tod@s aquel@s que não estão do lado desse governo inescrupuloso! (Carolina Giliolli Goos, 07/02/2020, em depoimento escrito por meio do WhatsApp).

Já em discursos de campanha, Bolsonaro mostrava a sua visão de democracia. Em 2017, em Campina Grande (PB), ele afirmava que "as minorias" teriam de "se curvar às maiorias". Estas passam a ser uma espécie de "rolo compressor" capaz de nivelar cenários complexos a partir da percepção sociologicamente difícil de sustentar de que um Estado democrático é aquele que governa para um todo numérico, sem se ater às necessidades de minorias políticas. As minorias

${ }^{18}$ O relato no bar da rua de Belleville foi construído com a ajuda das notas de campo produzidas por Julien J. Bourgier, doutorando em Sociologia na École d'Hautes Études em Sciences Sociales (EHESS), nascido na França e solidário ao movimento contra o avanço do fascismo no Brasil. 
contempladas, então, parecem ser aquelas ligadas aos lobbies que o elegeram (evangélicos, agronegócio, militares e indústria das armas). Apesar de seu caráter científica e empiricamente questionável (abstinência sexual para adolescentes, liberação do porte de armas) e efeitos sociais nocivos (precarização do trabalho, aumento da miséria e legitimação da violência policial), as políticas implementadas até o momento justificam o moral baixo de nossas entrevistadas. Apesar destas avaliações, nossas entrevistadas são unânimes em reconhecer a importância do movimento Mulheres Unidas Contra Bolsonaro, tanto no Brasil quanto em sua força transnacional, como marco histórico da luta de mulheres, dos feminismos e pela democracia no País. Contabilizam também os saldos desse engajamento em termos pessoais e na promoção de redes de solidariedade. "Mas o outro lado da gangorra foram as amizades desfeitas [...] Em 2018, depois das eleições, foi o pior momento, assim, com a família. Na verdade, ninguém teve Natal", ironiza Narayana Sad, quem, aos 43 anos, debutou no movimento feminista por meio do \#paslui, na França. "Esse movimento [refere-se ao \#elenão] impactou positivamente a vida de muitas mulheres que começaram a se enxergar como personagens de sua própria história", avalia.

Ao mesmo tempo em que têm de lidar com o sentimento de derrota e com o esgotamento emocional provocado pelo primeiro ano de governo Bolsonaro, nossas entrevistadas estão reinventando formas de enfretamentos e militância. "As grandes manifestações, aqui no Brasil, não tem mais", diz Carolina Goos, quem diz estar militando com "segurança". Naná, apesar do sentimento de que o \#elenão murchou, vai de luta em luta e tem passado a maior parte do tempo com as "Mulheres de Coletes Amarelos" ("Femmes Gilets Jaunes"), ${ }^{19}$ na França, e, na sua última passagem pelo Brasil, quando acontecia a greve dos petroleiros em 2020, via nesse movimento a esperança que o país se mexesse. Já Mariana Schmitz optou por sair do Facebook e se manter conectada a algumas redes de ativismos e militância por meio do WhatsApp. Ao contrário de Carolina, quem sente a repressão forte aos movimentos sociais no presente, Schmitz a percebe como menos truculenta do que havia projetado quando, durante a campanha eleitoral, acompanhava as falas do atual presidente, ainda como candidato, e os comentários de seus e suas partidários e partidárias.

Eu sou uma pessoa bem pessimista, então, eu imaginava, quando eu voltei para o Brasil, enfim... o discurso desse governo é muito truculento, né, muito brutal, muito limitado também. Curto e grosso, digamos assim. Mas eu acredito que é muito mais "ladra mais não morde". Quer dizer, morde. Claro que o que ele faz causa prejuízos ao país, óbvio. Sobretudo as relações internacionais, as questões ambientais, indígenas, vão ter consequências que vão ser eternas a partir deste governo, eu acho. Mas tendo em vista tudo que eles queriam fazer, é muito discurso e pouca realização. Não só porque a política representativa funciona assim, mas também, porque nesse caso, a incompetência é muito grande. Então, acho que eles não estão conseguindo. Eu achava que a perseguição política ia ser muito maior. Mas as pessoas ainda estão conseguindo sair nas ruas para se opor. [...] "Eu não acredito que haja um movimento de oposição organizado nesse momento. Existem movimentos separados, que não necessariamente compõem uma base unificada. A reforma da Previdência deixou isso bem claro. A gente está com uma capacidade de mobilização bem enfraquecida", analisa Mariana Schmitz.

Em comum, os relatos falam em silêncio do luto político como um momento necessário para reorganizarem-se emocional e politicamente. Vivê-lo é uma escolha, não uma sentença, e aí ele, o luto, se torna verbo, ação. A capacidade de agir politicamente não é sempre "um sinônimo de resistência em relações de dominação" (Saba MAHMOOD, 2006, p. 123).

Saba Mahmood (2006) se fundamenta em Judith Butler para construir sua proposta crítica à perspectiva liberal sobre agency a qual ela entende como dicotômica e, por isso mesmo, simplificadora de cenários complexos. Mahmood, em alguma medida, se distancia também da perspectiva feminista pós-estruturalista. Em seu diálogo com Butler, ela propõe que a agência não é sempre subversão da ordem. Analisando o contexto egípcio do movimento feminino das Mesquitas, a autora sugere que pensemos em agency para além dos atos de resistência. Desse modo, do ponto de vista da autora, mesmo em situações onde é difícil localizar uma forma explícita de agência, essa poderá ser observada no delineamento de limites para a dominação. Essa visão sobre agência, além de escapar teoricamente à dicotomia entre dominação e resistência, nos permite perceber ações normalmente lidas como docilidade, tais como recuo e sobrevivência, como efetivamente uma "modalidade de ação". Além disso, ajuda-nos a compreender a capacidade de agir como um fenômeno que não está restrito ao âmbito individual, mas que deve ser circunscrito a condições de possibilidade históricas, políticas e sociais.

Iniciamos com Butler e, por meio da sagacidade crítica de Mahmood, retornamos a ela. Pensando que "a lógica de subversão e ressignificação" das normas, sobretudo aquelas que

\footnotetext{
${ }^{19}$ Movimento social apartidário que, desde 17 de novembro de 2018 , tem saído semanalmente às ruas reivindicando políticas sociais mais igualitárias no âmbito do governo de Emmanuel Macron, acusado de "governar para os ricos", e até mesmo a sua renúncia do cargo de presidente. Em princípio, o movimento foi desencadeado em resposta ao aumento do preço do combustível e se organiza, atualmente, contra a proposta de reforma da previdência.
} 
conformam gêneros e sexualidades, não podem ser pré-determinadas, "porque os atos de ressignificação-subversão são, do seu ponto de vista, contingentes e frágeis, revelando-se em lugares inesperados e comportando-se de maneira imprevisível" (MAHMOOD, 2006, p. 135). Neste momento, quando ensaiamos um ponto final a esse texto de longa gestação, o imprevisível é nossa matéria. Assim, nosso artigo atua como registro da experiência produzida com essas mulheres, que foram capazes de produzir o alargamento da margem de manobra no político em tempos adversos para aquelas e aqueles que viram seus horizontes políticos e aspiracionais serem estreitados. Sujeitos cuja agência não se coloca "só como um sinônimo de resistência a relações de dominação, mas também como uma capacidade para a ação criada e propiciada por relações de subordinação específicas" (MAHMOOD, 2006, p. 133). Ambicionamos, assim, que as narrativas e reflexões trazidas em nosso artigo sejam um suporte para futuros modos de ação política disruptivos, quando as condições assim o permitam.

\section{Referências}

AMARAL, Marina. "Jabuti não sobe em árvore: como o MBL se tornou o líder das manifestações pelo impeachment”. In: JINKINGS, Ivana et al. (Eds.). Por que gritamos golpe? Para entender o impeachment e a crise política no Brasil. Tinta vermelha. 1. ed. São Paulo, SP: Boitempo, 2016. p. 44-47.

BALLESTRIN, Luciana. "O Debate Pós-democrático no Século XXI". Revista Sul-Americana de Ciência Política, v. 4, n. 2, p. 149-164, jan. 2018. Disponível em https://periodicos.ufpel.edu.br/ojs2/index.php/ rsulacp/article/view/14824/9146. Acesso em 20/04/2020.

BUTLER, Judith. Gender trouble: feminism and the subversion of identity. New York and London: Routledge, 1990.

BUTLER, Judith. Problemas de gênero: feminismo e subversão da identidade. Tradução de Renato Aguiar. 1. ed. Rio de Janeiro: Civilização Brasileira, 2006 a.

BUTLER, Judith. Trouble dans le genre: le féminisme et la subversion de l'identité. Tradução de Cynthia Kraus. Paris: La Découverte, 2006b.

BUTLER, Judith. A vida psíquica do poder: teorias da sujeição. Belo Horizonte: Autêntica, 2018.

BUTLER, Judith. Corpos em aliança e a política das ruas. Notas para uma teoria performativa de assembleia. 3. ed. Rio de Janeiro: Civilização Brasileira, 2019.

BUTLER, Judith; JAMI, Irène. "Considérer le problème plus que l'identité". In: REVUE MOUVEMENTS (Ed.). Pensées critiques. Dix itinéraires de la revue Mouvements 1998-2008. Poche/Sciences humaines et sociales. Paris: La Découverte, 2009. p. 117-130.

CARUSO, Marina. "Meu primeiro assédio". Época, 2015. Disponível em https://epoca.globo.com/ vida/noticia/2015/1 1/meu-primeiro-assedio.html. Acesso em 19/04/2020.

CASADO, Letícia; TUROLLO JR, Reynaldo. "PT vai ao STF contra Bolsonaro por vídeo em que ele defende 'fuzilar a petralhada'". Folha de S. Paulo, 2018. Disponível em https://www1 .folha.uol.com.br/poder/ 2018/09/pt-vai-ao-stf-contra-bolsonaro-por-video-em-que-ele-defende-fuzilar-a-petralhada.shtml. Acesso em 19/04/2020.

CATALANI, Felipe. "Aspectos ideológicos do bolsonarismo". Blog da Boitempo, 28/10/2018. Disponível em https://blogdaboitempo.com.br/2018/10/31/aspectos-ideologicos-do-bolsonarismo/. Acesso em 20/08/2019.

CETIC.BR. Pesquisa sobre o uso das tecnologias de informação e comunicação: pesquisa TIC Domicílios, ano 2018. Tabelas. São Paulo: Núcleo da Informação e Coordenação do Ponto BR NIC.br, 2019. Disponível em https://www.cetic.br/pesquisa/domicilios/indicadores. Acesso em 19/ $04 / 2020$.

COLLINS, Patricia Hill. "Learning from the Outsider Within: The Sociological Significance of Black Feminist Thought”. Social Problems, v. 33, n. 6, p. S14-S32, out. 1986.

DUPUIS-DÉRI, Francis. "Le discours de la 'crise de la masculinité' comme refus de l'égalité entre les sexes: histoire d'une rhétorique antiféministe". Cahiers du Genre, v. 52, n. 1, p. 119-143, jun. 2012.

FERREIRA, Carolina Branco de Castro. "Feminismos web: linhas de ação e maneiras de atuação no debate feminista contemporâneo". Cadernos Pagu, Campinas, n. 44, p. 199-228, jun. 2015. Disponível 
em http://www.scielo.br/scielo.php?script=sci_arttext\&pid=S0104-83332015000100199\&lng=en\&n rm=iso. http://dx.doi.org/10.1590/1809-4449201500440199. Acesso em 24/01/2020.

FOLHA DE S. PAULO. "ATOS de mulheres contra Bolsonaro reúnem milhares em mais de 30 cidades". Folha de S. Paulo, São Paulo, 29/09/2018. Disponível em https://www1.folha.uol.com.br/poder/2018/ 09/atos-de-mulheres-contra-bolsonaro-reunem-milhares-em-mais-de-30-cidades.shtml. Acesso em 20/08/2019.

FRANÇA, Vera. "Buscando explicações para o \#EleSim". Site do Laboratório de Análise de Acontecimentos (GrisLab). GrisLab, 2018. Disponível em https://grislab.com.br/buscandoexplicacoes-para-o-elesim/. Acesso em 19/04/2020.

FREIRE, Fernanda A. "Campanhas feministas na internet: sobre protagonismo, memes e o poder das redes sociais". Em Debate, Belo Horizonte, v. 8, n. 5, p. 26-32, jul. 2016. Disponível em http:// opiniaopublica.ufmg.br/site/files/artigo/03-Fernanda-Freire.pdf. Acesso em 20/04/2020.

G1 PORTAL DE NOTíCIAS. "Datafolha de 25 de outubro para presidente por sexo, idade, escolaridade, renda, região, religião e orientação sexual”. G1, 26/10/2018a. Disponível em https://g1 .globo.com/ politica/eleicoes/2018/eleicao-em-numeros/noticia/2018/10/26/datafolha-de-25-de-outubro-parapresidente-por-sexo-idade-escolaridade-renda-regiao-religiao-e-orientacao-sexual.ghtml. Acesso em 19/04/2020.

G1 PORTAL DE NOTÍCIAS. "Pesquisa Ibope de 23 de outubro para presidente por sexo, idade, escolaridade, renda, região, religião e cor". G1, 24/10/2018b. Disponível em https://g1.globo.com/ politica/eleicoes/2018/eleicao-em-numeros/noticia/2018/10/24/pesquisa-ibope-de-23-de-outubropara-presidente-por-sexo-idade-escolaridade-renda-regiao-religiao-e-cor.ghtml. Acesso em 19/ 04/2020.

GADELHA, Rejane; KERR, Roberta. "A Pequena Política e as Fake News contra a Candidata Mulher nas Eleições Presidenciais de 2018". EnFil - Revista Encontros com a Filosofia, Niterói, ano 8, n. 10, p. 1-21, dez. 2019.

GATINOIS, Claire. "Au Brésil, le rempart des femmes contre l'extrême droite". Le Monde.fr, Paris, 2/10/ 2018a. Disponível em https://www.lemonde.fr/ameriques/article/2018/10/02/au-bresil-le-rempart-desfemmes-contre-bolsonaro_5363180_3222.html. Acesso em 20/08/2019.

GATINOIS, Claire. "Ludimilla Teixeira, 'l'emmerdeuse' des pro-Bolsonaro”. Le Monde.fr, Paris, 22/10/ 2018b. Disponível em https://www.lemonde.fr/ameriques/article/2018/10/22/ludmilla-teixeira-lemmerdeuse-des-pro-bolsonaro_5372689_3222.html. Acesso em 20/08/2019.

GERALDES, Elen Cristina et al. (Orgs.). Mídia, misoginia e golpe. Brasília: FAC-UnB, 2016.

GÓES, Juliana. "Ciência sucessora e a(s) epistemologia(s): saberes localizados". Revista Estudos Feministas, Florianópolis, v. 27, n. 1, p. 1-11, maio 2019. Disponível em https://periodicos.ufsc.br/ index.php/ref/article/view/1806-9584-2019v27n148373. Acesso em 20/08/2019.

GOMES, Carla; SORJ, Bila. "Corpo, geração e identidade: a Marcha das vadias no Brasil”. Sociedade e Estado, Brasília, v. 29, n. 2, p. 433-447, 2014.

GORDON, Linda. The second coming of the KKK: the Ku Klux Klan of the 1920s and the American political tradition. New York: Liveright Publishing Corporation, 2017.

HAICAULT, Monique. "Autour d'agency. Un nouveau paradigme pour les recherches de Genre". Rives méditerranéennes, Toulouse, n. 41, p. 11-24, fev. 2012. Disponível em http://journals.openedition. org/rives/4105. Acesso em 20/08/2019.

HARAWAY, Donna. "Situated Knowledges: The Science Question in Feminism and the Privilege of Partial Perspective". Feminist Studies, Maryland, v. 14, n. 3, p. 575-599, 1988.

HARDING, Sandra. The science question in feminism. Ithaca and London: Cornell University Press, 1986.

HOBSBAWM, Eric. Sobre História. São Paulo: Companhia das Letras, 1998.

IBGE. INSTITUTO BRASILEIRO DE GEOGRAFIA E ESTATÍSTICA (ED.). Acesso à Internet e à televisão e posse de telefone móvel celular para uso pessoal, 2015: Pesquisa Nacional por Amostra de Domicílios. Rio de Janeiro: IBGE, Instituto Brasileiro de Geografia e Estatística, 2016. 
JAULMES, Adrien. "Bolsonaro, le 'Trump tropical' sorti d'un Brésil en ruine”. Le Figaro, 28/12/2018. Disponível em http://www.lefigaro.fr/international/2018/12/28/01003-20181228ARTFIG00228bolsonaro-le-trump-tropical-sorti-d-un-bresil-en-ruine.php. Acesso em 20/08/2019.

KALIL, Isabela Oliveira. "Notas sobre 'Os Fins da Democracia': etnografar protestos, manifestações e enfrentamentos políticos". Ponto Urbe, n. 22, p. 1-5, ago. 2018a. Disponível em http:// journals.openedition.org/pontourbe/3933. Acesso em 09/02/2020.

KALIL, Isabela Oliveira. "\#EleNão e \#EleSim: uma perspectiva feminista sobre os protestos em São Paulo e sua repercussão”. Blog da Boitempo, out. 2018b. Disponível em https://blogdaboitempo.com.br/ 2018/10/04/elenao-e-elesim-uma-perspectiva-feminista-sobre-os-protestos-em-sao-paulo-e-suarepercussao/. Acesso em 09/02/2020.

KIMMEL, Michael S. Angry white men: American masculinity at the end of an era. New York: Nation Books, 2013.

KRAUS, Chynthia. "Note sur la traduction". In: BUTLER, Judith. Trouble dans le genre: le féminisme et la subversion de l'identité. Paris: La Découverte, 2006. p. 21-24.

LINCOLN JR, Ronald; GERAQUE, Eduardo. "Protestos de mulheres contra Cunha param centro de São Paulo e Rio". Folha de S. Paulo, São Paulo, 2015. Disponível em http://www1 .folha.uol.com.br/ cotidiano/2015/1 1/1 705645-protestos-de-mulheres-contra-cunha-param-centro-de-sao-paulo-erio.shtml. Acesso em 19/04/2020.

MAHMOOD, Saba. "Teoria feminista, agência e sujeito liberatório: algumas reflexões sobre o revivalismo islâmico no Egipto". Etnográfica, Lisboa, v. 10, n. 1, p. 121-158, 2006.

MARIANO, Silvana Aparecida. "O sujeito do feminismo e o pós-estruturalismo". Revista Estudos Feministas, Florianópolis, v. 13, n. 3, p. 483-505, 2005.

MARTíN, María; ROSSI, Marina. "Mulheres protestam contra Cunha pela terceira vez em duas semanas". El País Brasil, 2015. Disponível em https://brasil.elpais.com/brasil/2015/11/12/politica/ 1447346906_965515.html. Acesso em 19/04/2020.

MBEMBE, Achille. Políticas da Inimizade. Lisboa: Antígona, 2017.

MONTENACH, Anne. "Introduction". Rives méditerranéennes, Toulouse, n. 41, p. 7-10, 2012.

NATANSHON, Graciela. "O que tem a ver as tecnologias digitais com gênero?". In: NATANSHON, Graciela (Org.). Internet em Código Feminino: Teorias e Práticas. Buenos Aires: La Crujía Ediciones, 2013.

NAVES, Marie-Cécile. Trump, la revanche de l'homme blanc. Paris: Textuel, 2018.

PELÚCIO, Larissa; PAZ, Diego. "A democracia sexual no coração da democracia. A centralidade do gênero para a leitura do presente - entrevista com Éric Fassin". Revista Interface - Comunicação, Saúde, Educação, Botucatu, v. 23, e190258, p. 1-12, 2019.

PISCITELLI, Adriana. "Recriando a (categoria) mulher?". In: ALGRANTI, Leila (Org.). A prática feminista e o conceito de gênero. Campinas: IFCH-Unicamp, 2002. p. 7-42.

ROSSI, Marina. "O dia em que relatos do primeiro assédio tomaram conta do Twitter". El País Brasil, 2015. Disponível em https://brasil.elpais.com/brasil/2015/10/22/politica/1445529917_555272.html. Acesso em 19/04/2020.

SALDAÑA, Paulo; TUROLLO JR, Reynaldo. "STF suspende queixa-crime contra Bolsonaro por defender 'fuzilar petralhada'”. Folha de S. Paulo, 2019. Disponível em https://www1 .folha.uol.com.br/poder/ 2019/02/stf-suspende-queixa-crime-contra-bolsonaro-por-defender-fuzilar-petralhada.shtml. Acesso em 19/04/2020.

SILVA, Sérgio Gomes da. "A crise da masculinidade: uma crítica à identidade de gênero e à literatura masculinista". Psicologia: Ciência e Profissão, Brasília, v. 26, n. 1, p. 118-131, 2006.

SILVEIRA, Daniel. "G1 - Protesto contra Eduardo Cunha reúne mulheres no Centro do Rio - notícias em Rio de Janeiro". G1, 12/1 1/2015. Disponível em http://g1 .globo.com/rio-de-janeiro/noticia/2015/ 11/protesto-contra-eduardo-cunha-reune-mulheres-no-centro-do-rio.html. Acesso em 19/04/2020.

SOLANO, Esther. "A bolsonarização do Brasil". In: ABRANCHES, Sérgio H. (Ed.). Democracia em risco? 22 ensaios sobre o Brasil hoje. São Paulo: Companhia das Letras, 2019. p. 203-212. 
SOLNIT, Rebecca. A mãe de todas as perguntas: reflexões sobre os novos feminismos. São Paulo: Cia. das Letras, 2017.

STANLEY, Jason. Como funciona o fascismo: A política do 'nós' e 'eles'. Tradução de Bruno Alexander. Porto Alegre: L\&PM Editores, 2018.

TRIBUNAL SUPERIOR ELEITORAL. "Brasil tem 147,3 milhões de eleitores aptos a votar nas Eleições 2018". Tribunal Superior Eleitoral, Brasília, 1/8/2018. Disponível em http://www.tse.jus.br/imprensa/ noticias-tse/2018/Agosto/brasil-tem-147-3-milhoes-de-eleitores-aptos-a-votar-nas-eleicoes-2018. Acesso em 20/08/2019.

VENTURI, Gustavo; GODINHO, Tatau (Eds.). Mulheres brasileiras e gênero nos espaços público e privado. São Paulo: Fundação Perseu Abramo, 2010.

Larissa Pelúcio (larissa.pelucio@unesp.br) é Livre-Docente em Estudos de Gênero, Sexualidade e Teorias Feministas. Atua como professora de Antropologia na Universidade Estadual Paulista Júlio de Mesquita Filho (campus Bauru, Departamento de Ciências Humanas FAAC), integra o quadro de docentes do Programa de Pós-Graduação em Ciências Sociais na mesma instituição (campus Marília). É também pesquisadora-colaboradora do Núcleo de Estudos de Gênero Pagu.

Diego Paz (diegopaz.psy@gmail.com) é doutorando, no Brasil, do Programa de PósGraduação em Psicologia Clínica na Universidade Católica de Pernambuco e, na França, no Département d'Études de Genre da Universidade Paris 8. Vinculado ao Laboratoire d'études de genre de sexualité (LEGS).

\section{COMO CITAR ESSE ARTIGO DE ACORDO COM AS NORMAS DA REVISTA}

PELÚCIO, Larissa; PAZ, Diego. "\#paslui: feminismos brasileiros no hexágono europeu”. Revista Estudos Feministas, Florianópolis, v. 28, n. 3, e71498, 2020.

\section{CONTRIBUIÇÃO DE AUTORIA}

Larissa Pelúcio e Diego Paz contribuíram igualmente na produção deste artigo quanto à concepção, coleta e análise de dados, elaboração do manuscrito, redação e discussão de resultados.

\section{FINANCIAMENTO}

O presente trabalho foi realizado com apoio da Fundação de Amparo à Pesquisa do Estado de São Paulo (FAPESP) e da Coordenação de Aperfeiçoamento de Pessoal de Nível Superior - Brasil (CAPES) - Código de Financiamento 001 .

\section{CONSENTIMENTO DE USO DE IMAGEM}

Não se aplica.

\section{APROVAÇÃO DE COMITÊ DE ÉTICA EM PESQUISA}

Não se aplica.

\section{CONFLITO DE INTERESSES}

Não se aplica.

LICENÇA DE USO

Este artigo está licenciado sob a Licença Creative Commons CC-BY Internacional. Com essa licença você pode compartilhar, adaptar, criar para qualquer fim, desde que atribua a autoria da obra.

\section{HISTÓRICO}

